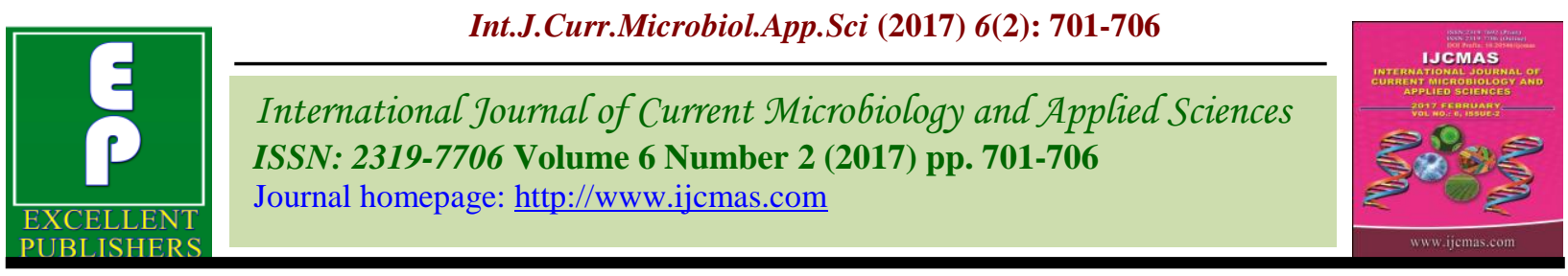

Original Research Article

http://dx.doi.org/10.20546/ijcmas.2017.602.079

\title{
Influence of Micro Irrigation and Drip Fertigation Practices on Yield and Quality Parameters of Robusta Coffee (Coffea canephora)
}

\author{
C. Babou*, Rudragouda, D.S. Mukharib, Kishor Mote, Nagaraj Gokavi, \\ Ramya, A.N. Manjunath and Y. Raghuramulu \\ Central Coffee Research Institute, Coffee Research Station Post - 577 117, \\ Chikmagalur District, Karnataka, India \\ *Corresponding author
}

\begin{abstract}
A B S T R A C T
Keywords

Clean coffee yield, Drip fertigation, NPK levels, Yield parameters, Yield and quality parameters.

Article Info

Accepted:

18 January 2017

Available Online:

10 February 2017

A field experiment was initiated in established Robusta coffee plantation with different levels of drip fertigation viz., 75, 100, 125 and $150 \%$ of recommended dose of fertilizers to study the influence of micro-irrigation and drip fertigation on yield and yield parameters of coffee at Central Coffee Research Institute. Results showed that drip fertigation with 125 $\%$ recommended dose of fertilizers recorded significantly higher bearing nodes per branch (24.87) and pin heads/branch (623.29) which was on par with treatment having drip fertigation of $100 \%$ of recommended dose of fertilizers (23.42 and 600.13 respectively) and $75 \%$ of recommended dose of fertilizers (23.12 and 591.42 respectively) over the control. Similarly, significantly higher clean coffee yield $(1008 \mathrm{~kg} / \mathrm{ha})$ was recorded in the treatment with $125 \%$ recommended dose of fertilizers drip fertigation and it was on par with the treatment received $100 \%$ recommended dose of fertilizers through drip fertigation $(960 \mathrm{~kg} / \mathrm{ha})$ which was followed by $75 \%$ recommended dose of fertilizers through drip fertigation (671 kg/ha). Higher grade quality ("AB") bean percentage was observed in the treatment with $100 \%$ recommended dose of fertilizers through drip fertigation $(61.62 \%)$ where as treatments received $125 \%$ and $75 \%$ recommended dose of fertilizers through drip fertigation recorded $59.26 \%$ and $58.14 \%$ respectively. Hence, the adoption the drip fertigation in coffee estates could increase productivity of coffee more than half as compared to coffee cultivated under conventional irrigation system.
\end{abstract}

\section{Introduction}

Rainfall variability and distribution make irrigation essential to produce quality coffee in agro-forest ecosystem in India. Water stress and inadequate nutrition predispose coffee plants to die back, affecting yields and bean quality. Improper management of irrigation in coffee plantation will limit the expansion of the coffee industry unless water is used at its optimum efficiency. Robusta coffee is more susceptible to drought and responds well to irrigation compared to Arabica coffee. The most important factor which limits the production of coffee even in well managed estates is the long dry period. Besides this, if blossom rains are delayed beyond March then the production of coffee receives a major setback.

Drip irrigation is an efficient method of providing irrigation water directly into soil at 
the root zone of plants and minimizes conventional losses such as deep percolation, runoff and soil erosion especially in water scarce areas having undulated topography, shallow soils and for wide spaced high value crops. It also permits the utilization of fertilizers, pesticides and other water-soluble chemicals along with irrigation water resulting in higher yields and better quality produce. Hence, drip irrigation system is regarded as panacea for many of the problems in drought prone areas (Carr, 2001 and Silva et al., 2008).

For coffee producers, a further advantage attributed to the irrigation method is the possibility of implementing drip fertigation, a practice which may result in substantial fertilizer savings (Muaralidhara et al., 2006 and Guimaraes et al., 2010). Several research evidences showed that drip fertigation in coffee resulted in substantial savings of fertilizer and increased the $27 \%$ of productivity (Serra et al., 2013). Keeping all these in view, a field trail was initiated during the year 2013-14 with an objective to know the influence of micro-irrigation and different levels of drip fertigation of $\mathrm{N}, \mathrm{P}$ and $\mathrm{K}$ fertilizers on yield and yield parameters of robusta coffee.

\section{Materials and Methods}

Field experiment was initiated in the already established (42 years old) Coffea canephora (syn. Coffea robusta) plantation at the spacing of $10 \times 10$ feet to study the influence of different levels of drip fertigation of N,P and $\mathrm{K}$ fertilizers on yield parameters and yield of coffee. The experiment was laid out with six treatments comprised of drip fertigation with $75,100,125$ and $150 \%$ of RDF, $100 \%$ RDF through soil application with drip irrigation and control (conventional practice) replicated four times in a randomized complete block design at the Division of Agronomy, Central Coffee Research Institute during the year
2014-15. The details of treatments are furnished below,

$\mathrm{T}_{1}$ - Control - $100 \%$ Recommended Dose of Fertilizer (RDF) as soil application + sprinkler (blossom irrigation at after $15^{\text {th }}$ February and backing irrigation at 20 days after blossom irrigation)

$\mathrm{T}_{2}-100 \% \mathrm{RDF}$ as soil application + Drip Irrigation

$\mathrm{T}_{3}$ - Drip Fertigation $+75 \% \mathrm{RDF}$ as Water Soluble Fertilizer (WSF)

$\mathrm{T}_{4}$ - Drip Fertigation $+100 \% \mathrm{RDF}$ as WSF

$\mathrm{T}_{5}$ - Drip Fertigation $+125 \% \mathrm{RDF}$ as WSF

$\mathrm{T}_{6}$ - Drip Fertigation $+150 \% \mathrm{RDF}$ as WSF

Each block was composed by the same number of coffee plants uniformly distributed along the same number of planting rows. Each one of these plots was composed by 10 consecutive plants along a continuous plant row segment. Four dripper/emitter were installed on these two lateral lines with an online pressure compensating with a 4 litres per head discharge, were uniformly installed spaced at $40 \mathrm{~cm}$. Other regular cultural operations such as weeding, plant protection measures were followed as per the Coffee Board recommendations (Coffee Guide, 2014).

The water soluble fertilizers such as urea, mono-ammonium phosphate (MAP) and muriate of potash (MOP) were used for drip fertigation treatments and drip fertigation was given twice a week. Di-ammonium phosphate (DAP), rock phosphate and muriate of potash were used for conventional treatments (Plate 1). During the study period, $2627 \mathrm{~mm}$ of rainfall was recorded. The recorded mean maximum and minimum temperature was 
$33.5^{\circ} \mathrm{C}$ and $16.5^{\circ} \mathrm{C}$ respectively. All the necessary cultural operations such as weeding, plant protection measures were carried as per package of practices (Coffee Guide, 2014) and the periodical observations were recorded and analyzed with appropriate statistical design (Gomez and Gomez, 1984) and discussed in the following results and discussion chapter.

\section{Results and Discussion}

\section{Yield parameters}

Preliminary results revealed that phenomenal increase in yield parameters such as bearing branches, bearing nodes/branch, fruit set percentage and clean coffee yield with increasing levels of water soluble fertilizers NPK through drip fertigation over the period of field study.

Among the various treatments, fertigation with $125 \%$ RDF recorded significantly higher bearing nodes per branch (24.87) pin heads/branch (623.29) and fruit set (83.26) at pin head stage which was on par with treatment having drip fertigation of $100 \%$ of RDF (23.42, 600.13 and 77.85 respectively) and $75 \%$ of $\operatorname{RDF}(23.12,591.42$ and 65.67 respectively) over the control (13.83, 480.14 and 43.21 respectively). Similar trend was observed in total branches, bearing branches and total nodes (Table 1). This might be due to continues application of irrigation and drip fertigation during dry months which helped in significant improvement in nutrient uptake there by increasing the yield parameters (Guimaraes et al., 2010). Even though treatment received drip fertigation with $125 \%$ RDF showed lesser number of total nodes (64.92) and bearing branches (9), it registered higher bearing nodes/branch (39.50) compared to control (Table 1; Plate 2 and 3).

\section{Clean coffee yield}

Significantly higher clean coffee yield (1008 $\mathrm{kg} / \mathrm{ha}$ ) was observed in the treatment with 125 $\%$ RDF drip fertigation and it was on par with the treatment received $100 \%$ RDF drip fertigation $(960 \mathrm{~kg} / \mathrm{ha})$ which was followed by $75 \%$ RDF drip fertigation $(671 \mathrm{~kg} / \mathrm{ha})$ whereas, lower clean coffee yield was recorded in the control (410 kg/ha) (Table 1; Plate 2 and 3). The results from this study are in close agreement with Rodrigues et al., (2010). This might be due to efficient utilization of water soluble fertilizers in continues approach (Serra et al., 2013).

Table.1 Influence of micro-irrigation and drip fertigation practices on yield parameters and clean coffee yield of Robusta

\begin{tabular}{|c|c|c|c|c|c|c|c|}
\hline Treatments & $\begin{array}{c}\text { Total } \\
\text { branches }\end{array}$ & $\begin{array}{c}\text { Bearing } \\
\text { branches }\end{array}$ & $\begin{array}{c}\text { Total } \\
\text { nodes }\end{array}$ & $\begin{array}{c}\text { Bearing } \\
\text { nodes / } \\
\text { branch }\end{array}$ & $\begin{array}{c}\text { Pin heads / } \\
\text { branch }\end{array}$ & $\begin{array}{c}\text { Fruit set } \\
(\%)\end{array}$ & $\begin{array}{c}\text { Clean } \\
\text { coffee yield } \\
\text { (kg/ha) }\end{array}$ \\
\hline $\mathrm{T} 1$ & 10 & 8 & 40.23 & 13.83 & 480.14 & 43.21 & 410 \\
\hline $\mathrm{T} 2$ & 13 & 8 & 60.50 & 20.67 & 531.88 & 57.86 & 523 \\
\hline $\mathrm{T} 3$ & 16 & 11 & 78.62 & 23.12 & 591.42 & 65.67 & 671 \\
\hline $\mathrm{T} 4$ & 18 & 12 & 82.54 & 23.42 & 600.13 & 77.85 & 960 \\
\hline $\mathrm{T} 5$ & 18 & 14 & 91.51 & 24.87 & 623.29 & 83.26 & 1008 \\
\hline $\mathrm{T} 6$ & 15 & 10 & 64.92 & 21.25 & 540.25 & 61.23 & 653 \\
\hline SEm \pm & 1.45 & 0.85 & 5.46 & 3.25 & 40.95 & 8.62 & 52.85 \\
\hline CD at 5\% & 4.38 & 2.05 & 16.46 & 9.41 & 118.33 & 26.11 & 162.43 \\
\hline
\end{tabular}


Fig.1 Influence of micro-irrigation and drip fertigation practices on percentage of " $\mathrm{AB}$ " and " $\mathrm{C}$ " grade beans of Robusta

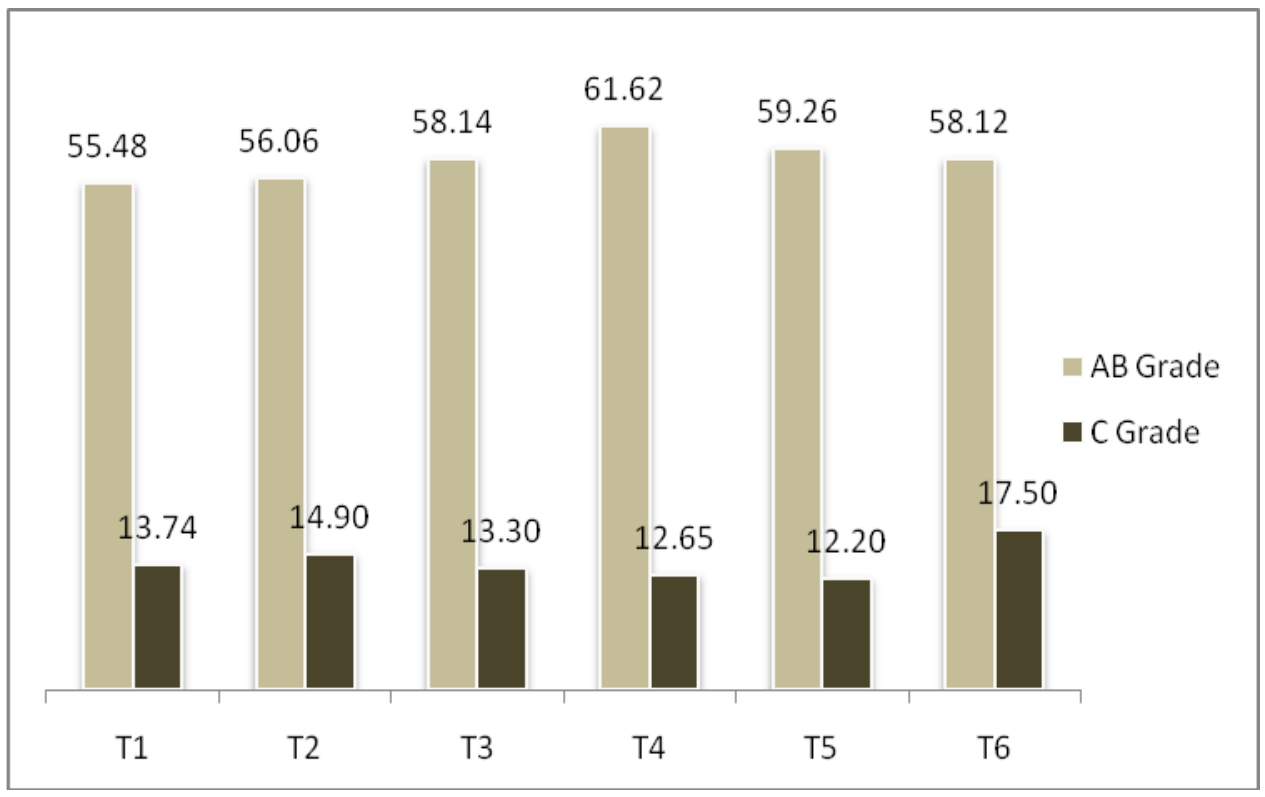

Fig.2 Influence of micro-irrigation and drip fertigation practices on percentage of "BB" and "PB" grade beans of Robusta

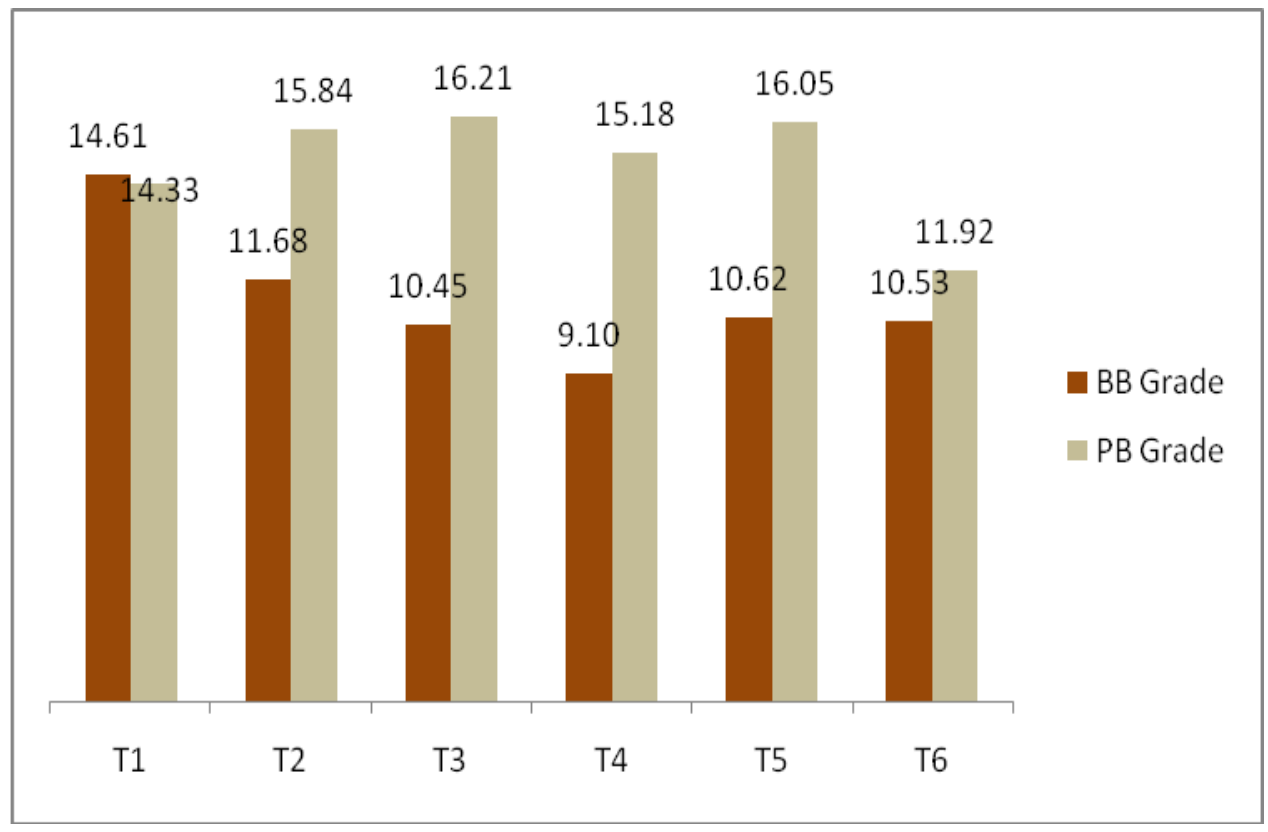


Plate.1 Methods and methodology used in this experimental trial

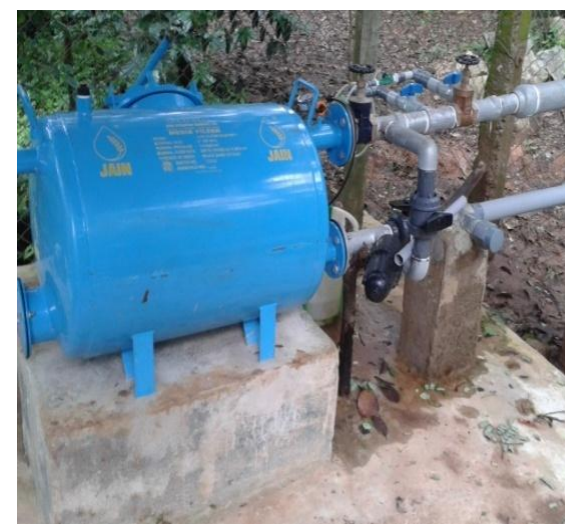

\section{Micro Irrigation System Unit}

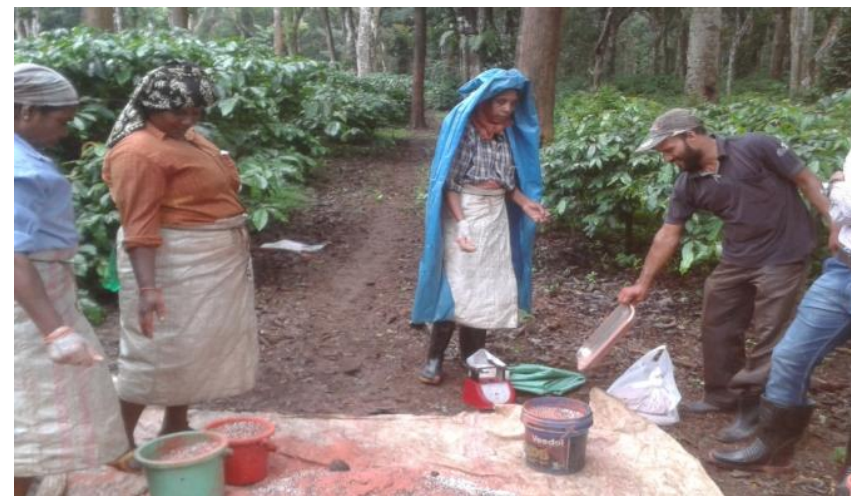

\section{Fertilizer for soil application - conventional practice}

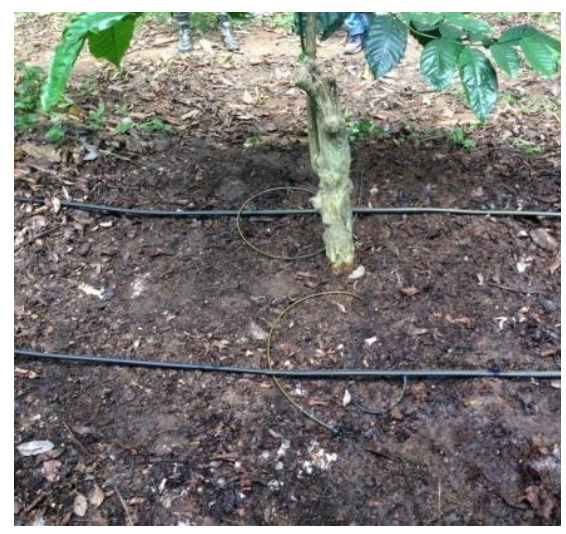

Drip irrigation (paired drip lines)

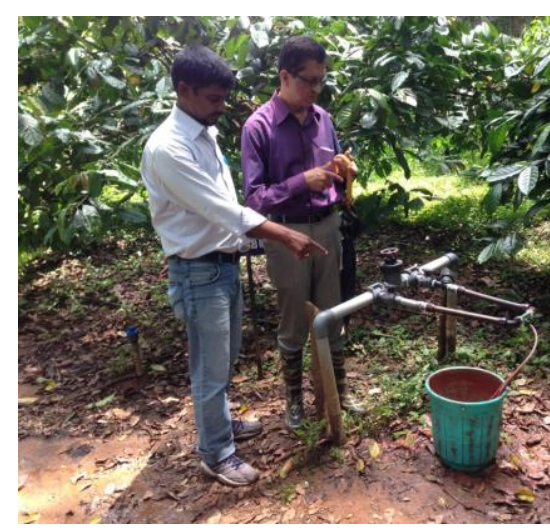

Drip fertigation through venturi

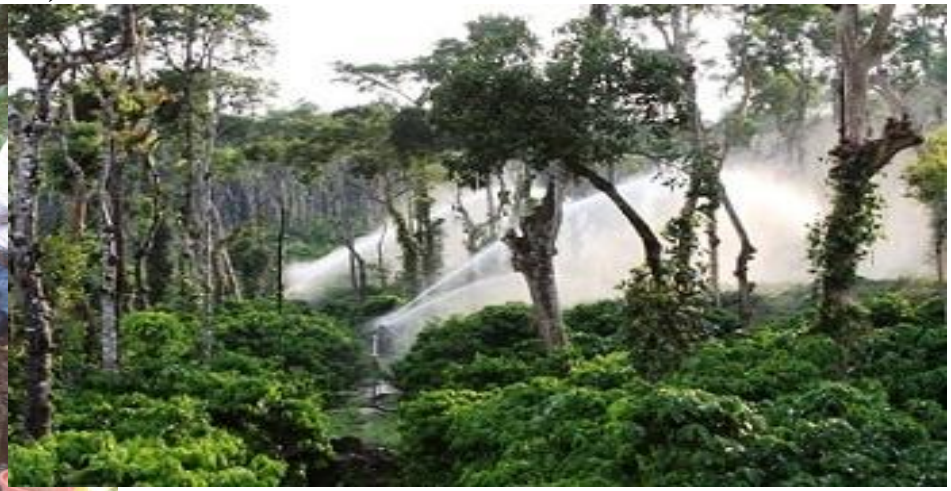

\section{Sprinkler irrigation through rain gun}

Plate. 2 and 3 Control plant with minimum fruits and drip fertigated coffee plant with more fruits
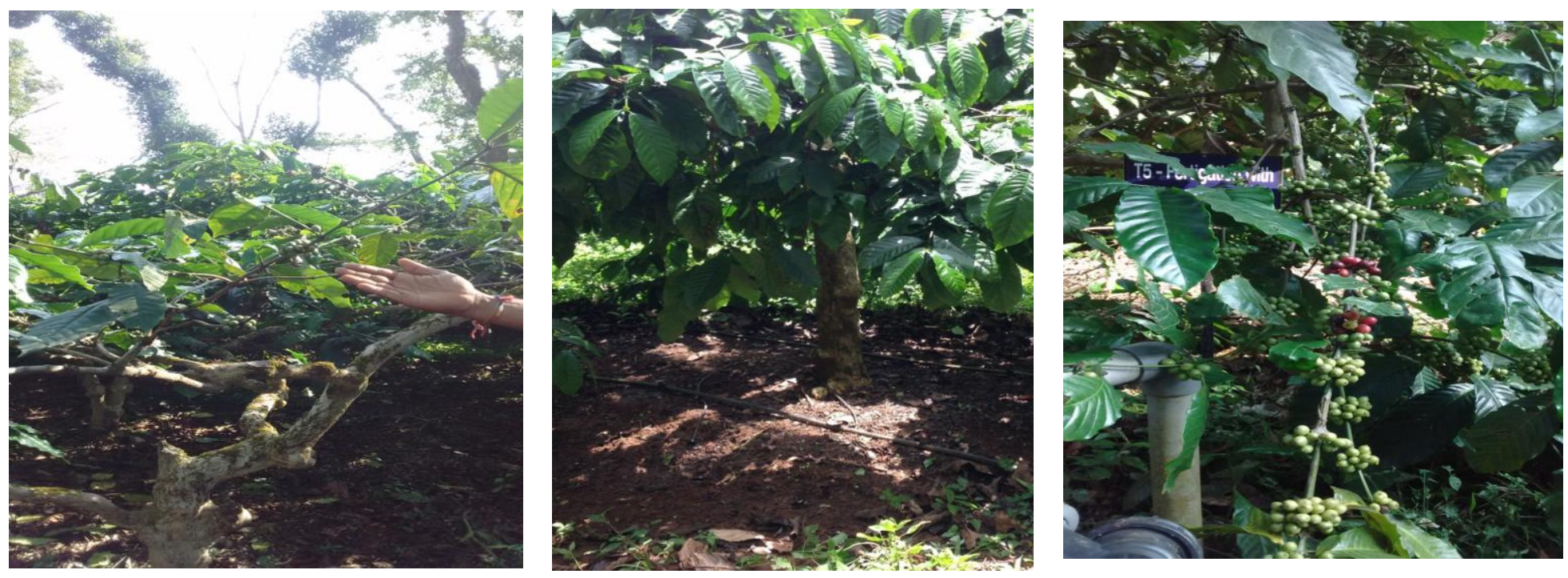


\section{Quality parameters}

The observations on different beans grade qualities were recorded (Fig. 1 and 2). Result revealed that higher grade quality ("AB") bean percentage was observed in the treatment with $100 \%$ recommended dose of fertilizers through drip fertigation (61.62\%) where as treatments received $125 \%$ and $75 \%$ recommended dose of fertilizers through drip fertigation recorded $59.26 \%$ and $58.14 \%$ respectively. Least number of "AB" grade beans was recorded in the control $(55.48 \%)$ and lower percentage of cuts beans recorded in the treatment with $100 \%$ recommended dose of fertilizers through drip fertigation. This might be due to drip irrigation permits the utilization of fertilizers and other water soluble chemicals along with irrigation water in continues approach resulting in higher yields and better quality produce (Shivakumar et al., 2001; Shashidhara et al., 2007 and Serra et al., 2013).

In conclusion, preliminary results of this study revealed that increase in yield parameters and clean coffee yield was observed with increasing levels of water soluble fertilizers (125\% RDF) through drip fertigation, significantly higher yield parameters and clean coffee yield were recorded in the treatment with $100 \%$ RDF through fertigation. Considering quantum of fertilizers application and cost of production, the treatment receiving 100\% RDF fertigation performed well which resulted in substantial fertilizer savings and makes potentially more efficient input management practice than other methods. Hence, cultivation of coffee could improve the fertilizer use efficiency and increase productivity by more than half by adopting the drip fertigation methods, compared to the coffee cultivated under conventional irrigation system.

\section{References}

Carr, M.K.V. 2001. The water relations and irrigation requirements of coffee. Experimental Agri., 37: 1-36.
Coffee Guide. 2014. Central Coffee Research Institute, Coffee Research Station, Government of India, Chikmagalur district, Karnataka, India.

Gomez, A.A., Gomez, K.A. 1984. Statistical procedures for agricultural research. Wiley and Sons Inc, New York. 680 p.

Guimaraes, R.J., Scalco, M.S. and Alexandre, L.P.B. 2010. Fertilization for fertigated coffee trees in the southern region of Minas Gerais. Coffee Sci., 5: 137.

Muaralidhara, H.R., Biradar, I.B., Kamala Bai, S., Raghuramulu, Y. 2006. Irrigation management in coffee. Indian Coffee, VLVIX (2).

Rodrigues, S., Ferreira, G.S. and Campos, A.F. 2010. Development of coffee submitted to different irrigation slides under the conditions of the state of Rondonia. Global Sci. Technol., 3: 44-49.

Serra, E.L., Scalco, M.S. and Guimarães, R.J. 2013. Functions of irrigated coffee production and under different planting densities. Coffee Sci., 8: 157.

Shashidhara, K.A., Bheemappa, L., Hirevenkanagoudar and Shashidhar, C. 2007. Benefits and constraints in adoption of drip irrigation among the plantation crop growers. Karnataka J. Agri. Sci., 20(1): 82 -84 .

Shivakumar, H., Ramachandrappa, B., Nanjappa, H.V. and Roopa devi, D. 2001. Micro irrigation for macro future. Agro India, 5: 18-19.

Silva, A., Bruno, I., Reichardt, K., Bachi, S., Costa, P. and Timm, L. 2008. Soil water extraction by roots and $\mathrm{Kc}$ for the coffee crop. Brazilian J. Agri. Environ. Engi., 13(3): 257.

\section{How to cite this article:}

Babou, C., Rudragouda, D.S. Mukharib, Kishor Mote, Nagaraj Gokavi, Ramya, A.N. Manjunath and Raghuramulu, Y. 2017. Influence of Micro Irrigation and Drip Fertigation Practices on Yield and Quality Parameters of Robusta Coffee (Coffea canephora). Int.J.Curr.Microbiol.App.Sci. 6(2): 701-706. doi: http://dx.doi.org/10.20546/ijcmas.2017.602.079 